\title{
Selecting the Optimal ERP Software by Combining the ISO 9126 Standard and Fuzzy AHP Approach
}

\author{
Shing-Ko Liang \\ National Chiao-Tung University and China University of Technology \\ E-Mail: skliang@cc.nctu.edu.tw \\ Chi-Tai Lien \\ National Chiao-Tung University and Ta-Hwa Institute of Technology \\ E-Mail: chitailien.iem91g@nctu.edu.tw
}

\begin{abstract}
Enterprise resource planning (ERP) software is one of costly and crucial projects for business investment. Due to the selection criteria of ERP software are numerous and fuzziness, selecting the optimal ERP software is a critical process in the early phase of an ERP project. This paper presents a practical procedure which combines both the ISO 9126 standard and the fuzzy analytic hierarchy process (FAHP) approach to optimize the ERP selection problems.

There are total 32 criteria sifted out which include 21 software quality criteria of ISO 9126 standard. Two practical cases which belong to different industries are applied to illustrate the practicality of the procedure, one is semiconductor manufacturing industry and another is chain store retailer service industry. We find that there are diverse weights for software quality criteria between these two industries. We also find that the cost issue and time issue are significantly important in both two cases.
\end{abstract}

Keywords: ERP, Decision Making, ISO 9126 Standard, FAHP

\section{INTRODUCTION}

Due to the improvement of computer hardware and software capability, Enterprise Resource Planning (ERP) system had grown into an integrated software solution which is 
capable to run every function of an organization since the early 1990s, (Kapp, 2001). ERP is a method for effective planning, and control for all resources needed to take, make, ship and account for customer orders in a manufacturing, distribution and service company (APICS Dictionary, 1998).

As a result of the complexity of the business environment, the limitations in available resources and the diversity of ERP alternatives, ERP software selection is tedious and time consuming (Wei and Wang, 2004). Therefore, ERP software selection is crucial in the early phase of an ERP project.

This paper presents a practical procedure to optimize the alternatives of ERP software. This procedure combines both the ISO 9126 standard and the fuzzy analytic hierarchy process (FAHP) approach, thus it is excellent to solve the decision making problems and facilitates group fuzzy decision making process.

Two practical cases in Taiwan which belong to different industries, one is semiconductor manufacturing industry (company A) and another is chain store retailer service industry (company B), demonstrate the practicality of the procedure. Owing to the different users requirements of ERP software might exist interactions and trade-offs (Nixon, 2000). Both cases are also compared the similarities and dissimilarities between them.

\section{PREVIOUS RESEARCH}

\section{ERP Software Selection Method}

Qualitative methods are very widely used in the past to score, rank, optimize and analysis the ERP software or other information technology (IT) system selection problem. Scott and Kaindl (2000) proposed a conceptual model for ERP package enhancement. Verville and Halingten (2003) also suggested a six-stage model to evaluate ERP software. However, the quantitative methods were more often been used. Buss (1983) presented a ranking method in the early periods of IT projects. Rao (2000) evaluated ERP software package by using decision tree. Kumar et al. (2002) applied basic statistics in a real ERP selection case. Mathematical optimization methods such as goal programming, 0-1 binary programming and non-linear programming are also widespread been presented (Santhanam and Kyparisis, 1995, 1996, Lee and Kim, 2000, Talluri, 2000). Owing to the essence of IT system selection problem is a multi criteria decision making (MCDM) process, several papers adopted analytic hierarchy process (AHP) to be the analytical tool (Schniderjans and Wilson, 1991, Wei et al., 2005). 


\section{Selection Criteria of ERP Software}

When implementing an ERP project, price and time are both the most important factors, besides, the vender's support is also a crucial issue (Langenwalter, 2000). Except the investment cost of ERP project, the annual maintenance cost and human resource cost are also the potential expense for organizations (Butlar, 1999, Bingi et al., 1999). Wei and Wang (2004) sift three categories of attributes to select an ERP system including project factors, software system factors and vender factors. Everdingen et al. (2000) explored that software system and supplier are the major criteria which contents 10 sub criteria for selecting an ERP system. Bernroider and Koch (2001) even found that the priorities of criteria are different between small-medium sized company and large sized company. The system integration between existing information systems and ERP system is a further technical problem which might complicate the entire ERP project (Holland and Light, 1999).

\section{Software Quality Model}

McCall et al. (1977) earliest proposed a prototype of software quality model which contents 11 criteria. Boehm et al. (1978) enlarged the characteristics of software and incorporates 19 criteria. Grady and Caswell (1987) defined five major factors containing 24 attributes for software quality and named FURPS model. These quality models are very similar to one another in many respects but differ mainly in terminology. Therefore, ISO 9126 standard (1991) standardized these quality models and drawn on the various quality models to produce a small set of six consistent characteristics, which give coverage of the main concepts of interest. The ISO 9126 software quality model is also been chosen to describe the software quality characteristics in our proposed procedure.

\section{FAHP and Fuzzy Set Theory}

Frequently, human judgments are often ambiguous and cannot estimate his/her preference with a crisp numerical value (Herrera and Herrera-Viedma, 2000). Fuzzy set theory is developed for solving problems in which description of activities and observations are imprecise, vague and uncertain. Since Buckley (1985) incorporated the fuzzy set theory into the traditional AHP, FAHP were becoming a suitable tool to solve the real-world MCDM problems (Buyukozkan et al., 2004, Huang and Wu, 2005). FAHP had used to select e-marketplace software and evaluated the public transport system (Buyukozkan, 2004, Hsu, 1999). Other fuzzy set theories are also popularly adopted. 
Cheng and Lin (2002) adopted fuzzy Delphi method to evaluate the best main battle tank. A fuzzy multi criteria group decision making approach was proposed to select configuration items for software development (Wang and Lin, 2003).

\section{PROCEDURE FOR THE OPTIMAL ERP SOFTWARE SELECTION}

This section presents our proposed procedure which is containing five stages (See Figure 1). A stepwise progress is readily described as follows:

Stage 1: Project initiation and requirements identification

Stage 2: Feasible software search and selection criteria extraction

Stage 3: Hierarchy construction for ERP software

Stage 4: Computing by FAHP approach

Stage 5: Selecting the optimal ERP software

\section{Selection Criteria Extraction of ERP Software}

Software quality criteria

The 21 criteria of ISO 9126 standard is chosen to describe the ERP software quality characteristics. This software quality model identifies six key quality attributes. The detailed characterization is presented as follows (Bache and Bazzana, 1994) (See Figure 2).

(1)Functionality

This attribute is defined as the degree to which the software functions satisfies stated or implied needs and can be broken down into five sub-characteristics as follows: suitability, accuracy, interoperability, compliance and security.

(2)Reliability

This attribute is defined as the capability of software that could maintain its level of performance under stated conditions for a stated period of time. It can be decomposed into three sub-characteristics as follows: maturity, fault tolerance and recoverability.

(3)Usability

This attribute is defined as the degree to which the software is available for use and can be broken down into three sub-characteristics as follows: understandability, learnability and operability. 


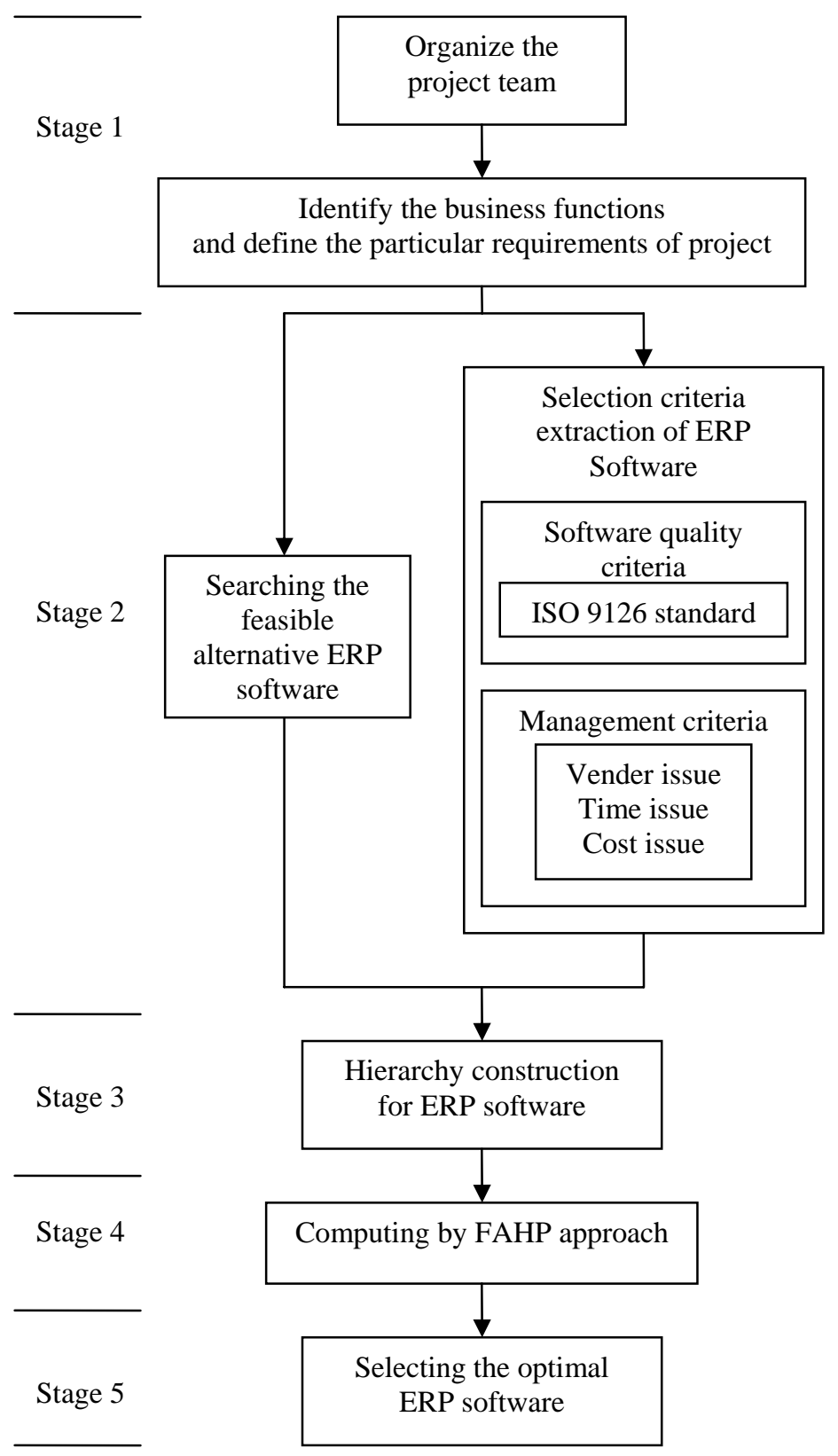

Figure 1 Procedure for optimal ERP software selection 


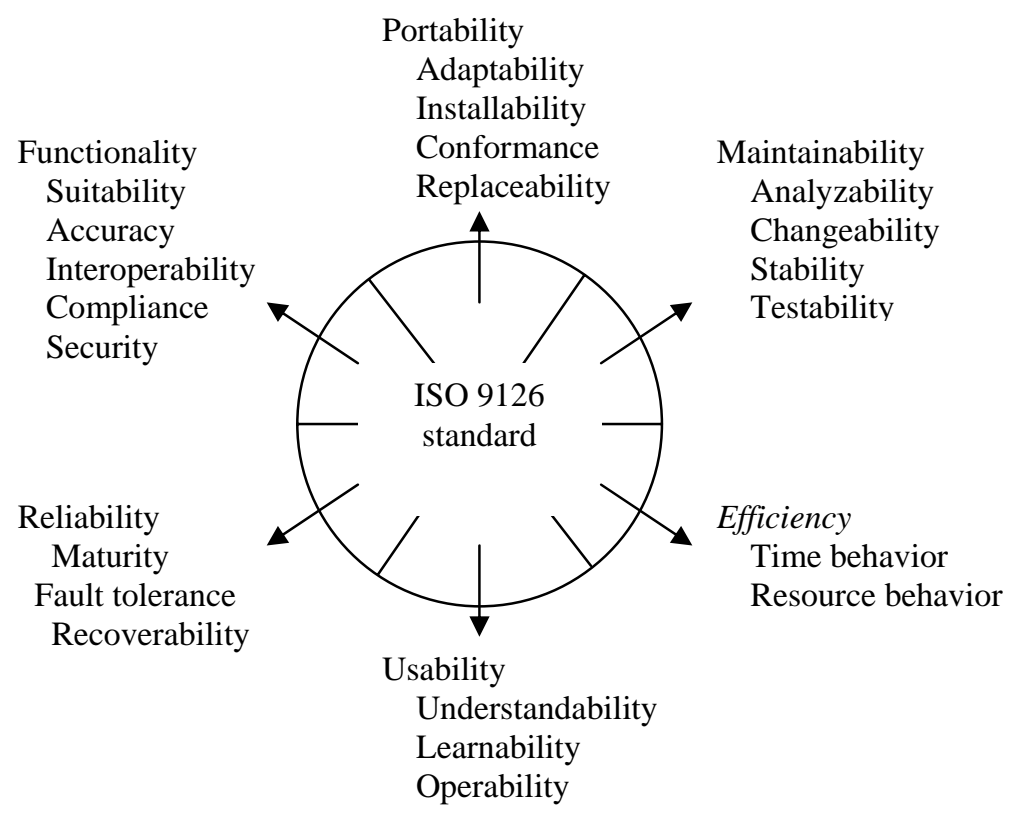

Figure 2 ISO 9126 standard

(4)Efficiency

This attribute is defined as the degree to which the software makes optimal use of system resources. It can be decomposed into two sub-characteristics as follows: efficiency of time behavior and efficiency of resource behavior.

(5)Maintainability

This attribute is defined as the ease with which repair may be made to the software and can be broken down into four sub-characteristics as follows: analyzability, changeability, stability and testability.

(6)Portability

This attribute is defined as the ability of software that can be transferred from one environment to another. It can be decomposed into four sub-characteristics as follows: adaptability, installability, conformance and replaceability.

\section{Management criteria}

As mentioned above, the generally selection criteria of ERP system contents three major criteria: vender factors, cost factors and time factors. By the way of literature review and deep interview with two project teams of company A and company B, we sift out four sub criteria of vender factors and four sub criteria of cost factors. And then we 
sort three time fences of the ERP project road map to be the sub criteria of time factors.

Consequently, total 11 sub criteria have decomposed from three major criteria. The 11 criteria are displayed as follows, and we categorize them to the management criteria.

(1) Sub criteria of vender factors: market share and reputation, industrial credential, service and support, training solution.

(2) Sub criteria of cost factors: software cost, hardware cost, annual maintenance cost, staff training cost.

(3) Sub criteria of time factors: time for planning and preparation, time for BPR and system tuning, time for testing and go-live.

\section{FAHP Approach and Defuzzification Policy}

\section{FAHP stepwise procedure}

\section{Step 1: Create the hierarchies}

According to the problem characteristics, to decompose each attribute and build up the hierarchy structure, the $0^{\text {th }}$ layer represents the ultimate goal; the $1^{\text {st }}$ layer represents the primary aspects that affect the ultimate goal; the $2^{\text {nd }}$ layer represents the major decision criteria of the $1^{\text {st }}$ layer, and so on. The last layer represents the alternate choices of the feasible solutions.

Step 2: Create fuzzy pairwise comparison matrix

According to the layer structure built up in Step 1, the decision importance criteria converted into the semantic format were used to design polling questionnaires. The next phase was to convert the results of the questionnaire into fuzzy pairwise comparison matrix by using Saaty’s 9 scales.

Step 3: Group combination (unification, integration)

After creating the fuzzy pairwise comparison matrix, the geometric mean of each criteria in the matrix was calculated as Buckley suggested.

Step 4: Build up the fuzzy positive reciprocal matrix

After Step 3, obtaining the final calculated fuzzy numbers for each layer could form the fuzzy positive reciprocal matrix.

Step 5: Calculate the key factors' fuzzy weights

The formulas are suggested by Buckley's fuzzy AHP model.

Step 6: Hierarchy layer sequencing

In the final step, the sequential layers are linked together to calculate the final fuzzy weight values for each alternative. 
Defuzzification policy

We adopt the center of gravity method to be the defuzzification policy. The defuzzified number is calculated by formula (1).

$U^{*}(C)=\frac{\int_{-c}^{c} C(z) z d z}{\int_{-c}^{c} C(z) d z}$

$U^{*}(C)$ : is defined as the value within the range of variable $v$.

Where the area under the graph of membership function $C$ is divided into two sub areas.

\section{TWO APPLICATIONS}

There are two kinds of ERP selection attributes that had been classified as mentioned above, software quality attributes and management attributes, respectively. For the software quality attributes, we introduced ISO 9126 standard including six major criteria and 21 sub criteria to be the assessing attributes. Further, three major criteria including 11 sub criteria in the management attributes were also explored. Finally, the hierarchy structure of ERP selection model is established in Figure 3.

The ultimate goal and two kinds of ERP selection attributes are set in $0^{\text {th }}$ layer and $1^{\text {st }}$ layer, respectively. The $2^{\text {nd }}$ and $3^{\text {rd }}$ layers belong to major criteria and sub criteria, and the feasible ERP software are put in the alternative layer. Two empirical cases in Taiwan, company A and B, belong to different industries were conducted to prove the practicality of our proposed procedure. 


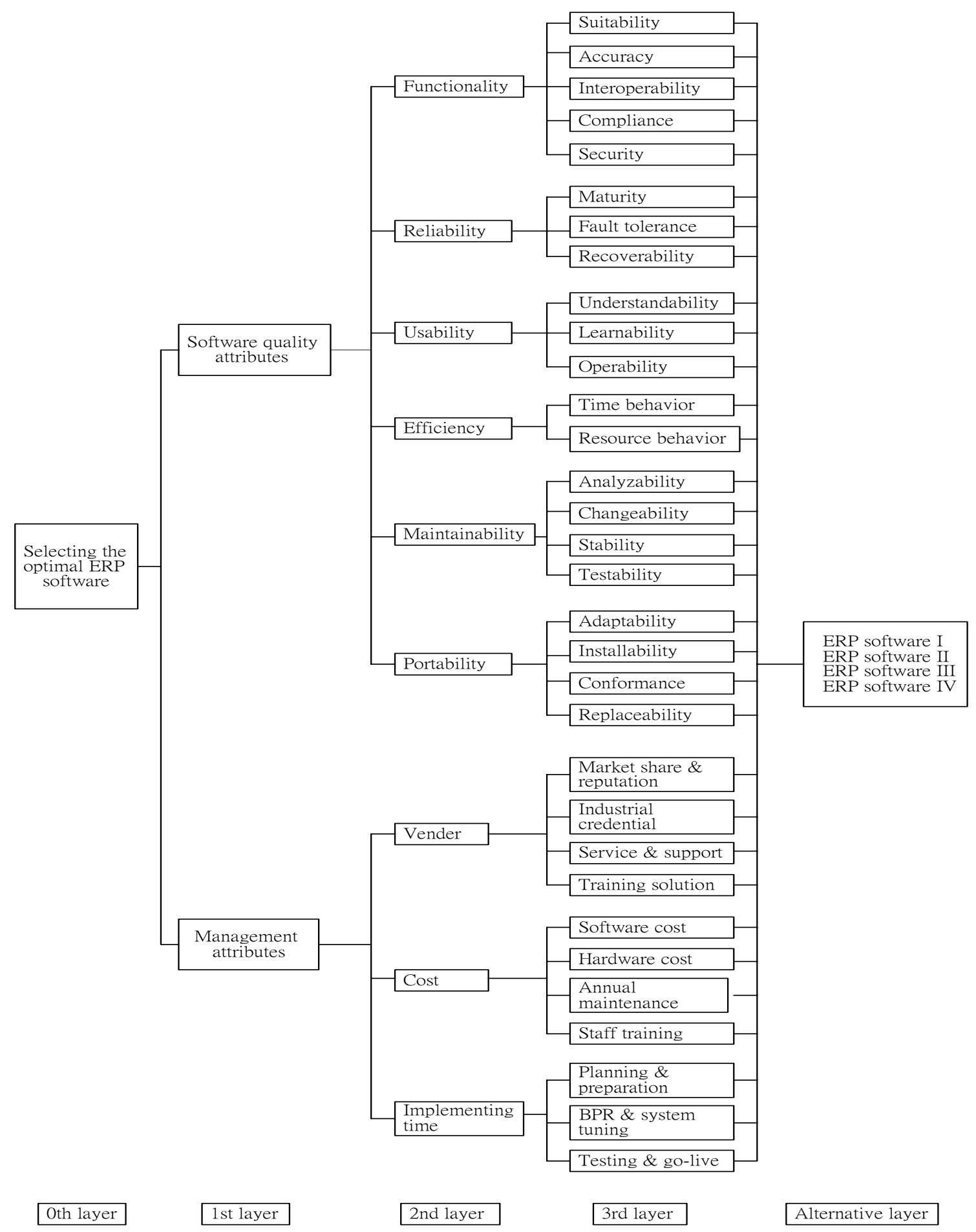

Figure 3 Hierarchy structure of ERP software selection problem 


\section{Company A: Semiconductor Manufacturing Industry}

Background illustration

Company A is an IC (integrated circuit) testing firm which is located in Hsinchu Industrial Park. This company who provides a total semiconductor testing solution tests both wafersand IC chips for customers, so customer requirements are extremely important for this company. In order to enhance the competition in industry and meet the customer demand, company A determines to integrate the various information systems in every department within the ERP software.

Stage 1: Project initiation and requirements identification

Firstly, the general manager of company A organizes the project team including nine senior managers in different departments: administration, finance, marketing, manufacturing, quality assurance, information technology and three product engineer departments. The general manager also identifies several distinctive requirements and the qualified ERP software should provides the following functions:

(1) The original MES (manufacturing execution system) must be integrated in the ERP software.

(2) The ERP software could expend to SCM (supply chain management) and link the APS (advanced planning and scheduling) system.

(3) The CRM (customer relationship management) function is an additional plus.

Stage 2: Feasible software search and selection criteria extraction

Once the requirements and the particular functions of ERP software are well defined, the project team could search qualified ERP software. After the preliminary screening by the limitation with budget, time and software functions, four feasible ERP software alternatives are came out. Among the four candidate alternatives, software I is an European product, software II is an American product, software III and IV are the local product in Taiwan.

Further, total 32 criteria including 21 criteria of ISO 9126 standard and 11 criteria of management attributes are extracted to describe the ERP software quality characteristics and management characteristics, respectively.

Stage 3: Hierarchy construction for ERP software

The hierarchy structure with layer $0^{\text {th }}, 1^{\text {st }}, 2^{\text {nd }}$ and $3^{\text {rd }}$ for company A and the alternative layer is located four software solutions (i.e., I, II, III and IV) as shown in Figure 3. 


\section{Stage 4: Computing by FAHP approach}

Firstly, we constructed a table of a set of question to identify ISO 9126 standard (see Table 1).

Then using the hierarchy structure of total 32 criteria and the stepwise FAHP approach as mentioned above, the fuzzy weights of layer $1^{\text {st }}, 2^{\text {nd }}$ and $3^{\text {rd }}$ are calculated by nine senior managers. After the fuzzy weights of each layer has been computed and linked together, the final fuzzy weights of entire 32 criteria is calculated as shown in Table 2. Table 3 lists the fuzzy scores for four alternatives relative to the first criteria "Suitability", and other fuzzy scores for four alternatives relative to remaining 31 criteria are computed as the same way. Ultimately, the final assessment result is presented as Table 4.

Stage 5: Selecting the optimal ERP software

Base on the computation result in Table 4, the American ERP software II is the dominant solution in the final rank. And the nine senior managers decide that system II is the optimal decision for their company.

Table 1 A set of questions to identify ISO 9126 standard

\begin{tabular}{|c|c|}
\hline ISO 9126 standard & Questions of linguistic expression to identify the ISO 9126 standard \\
\hline Suitability & $\begin{array}{l}\text { * The modules could fit the project propose, business processes and } \\
\text { the current missions of the company. }\end{array}$ \\
\hline Accuracy & $\begin{array}{l}\text { * The output data report of ERP software is absolutely identical with } \\
\text { the conventionally manual way. }\end{array}$ \\
\hline Interoperability & $\begin{array}{l}\text { * The output data of ERP software could be applied to other } \\
\text { application systems such as POS (point of sales system), EOS } \\
\text { (electronic order system), MES (manufacturing execution } \\
\text { system), APS (advanced planning and scheduling system), CRM } \\
\text { (customer relationship management system) and BI (business } \\
\text { intelligence system), etc. }\end{array}$ \\
\hline Compliance & $\begin{array}{l}\text { * The software is developed by the popular CASE (computer-aided } \\
\text { software engineering) tools. } \\
\text { * The software developing process conforms to software-related } \\
\text { standards such as CMM (capability maturity model), etc. }\end{array}$ \\
\hline Security & $\begin{array}{l}\text { * The software provides various functions of security such as data } \\
\text { encryption techniques, firewalls and authority access settings, etc. }\end{array}$ \\
\hline
\end{tabular}


Table 1 A set of questions to identify ISO 9126 standard (Continued)

\begin{tabular}{|c|c|}
\hline ISO 9126 standard & Questions of linguistic expression to identify the ISO 9126 standard \\
\hline Maturity & $\begin{array}{l}\text { * The software has been implemented in other companies of the } \\
\text { same industries, and holds high customers' satisfaction. }\end{array}$ \\
\hline Fault tolerance & $\begin{array}{l}\text { * The software has the ability to maintain a specified level of } \\
\text { performance when the software faults or the users infringe the } \\
\text { SOP (standard operation procedure). }\end{array}$ \\
\hline Recoverability & $\begin{array}{l}\text { * The recovering and resuming process is automatic performing, and } \\
\text { the recovered data is completely correct. } \\
\text { * There are at least } 2 \text { redundancies of backup modes such as hard- } \\
\text { disk, CD-ROM and tape, etc. }\end{array}$ \\
\hline Understandability & $\begin{array}{l}\text { * The logic concepts of software modules are similar to the actual } \\
\text { business processes. }\end{array}$ \\
\hline Learnability & $\begin{array}{l}\text { * The software provides help functions, and the software company } \\
\text { provides multilingual manuals such as English and Chinese, etc. } \\
\text { * The consultant provides the BPR (business process reengineering) } \\
\text { training to make the logic concepts of software more } \\
\text { understandable. }\end{array}$ \\
\hline Operability & $\begin{array}{l}\text { * The GUI (graphical user interface) and window interface are } \\
\text { available. } \\
\text { * The software supports multilingualism such as English and } \\
\text { Chinese, etc. }\end{array}$ \\
\hline Time behavior & $\begin{array}{l}\text { * The response time of report is reduced under the equivalent data } \\
\text { processing loading. }\end{array}$ \\
\hline Resource behavior & * The resource duration that is suggested by the supplier. \\
\hline $\begin{array}{l}\text { Analyzability } \\
\text { Changeability }\end{array}$ & $\begin{array}{l}\text { * The software could record the log files of all transactions. } \\
\text { * The software is well-modularized } \\
\text { * There are high-level cohesion and low-level coupling between the } \\
\text { software modules to avoid ripple effect. }\end{array}$ \\
\hline $\begin{array}{l}\text { Stability } \\
\text { Testability }\end{array}$ & $\begin{array}{l}\text { * The software would not failure after the customizing modification. } \\
\text { * The software has particular test programs for each function of } \\
\text { every module. }\end{array}$ \\
\hline Adaptability & $\begin{array}{l}\text { * The software could be installed on various operation systems such } \\
\text { as UNIX and Windows, etc. } \\
\text { * The software could automatically process the dependence between } \\
\text { modules. } \\
\text { * One step installation when initiation. }\end{array}$ \\
\hline
\end{tabular}


Table 2 Final fuzzy weights of entire 32 criteria for company A

\begin{tabular}{|c|c|c|c|}
\hline \multicolumn{3}{|c|}{ Hierarchy of criteria } & \multirow{2}{*}{ Fuzzy weight } \\
\hline Attribute & Major criteria & Sub criteria & \\
\hline \multirow[t]{21}{*}{ Software quality } & Functionality & Suitability & $(0.00945,0.01840,0.04122)$ \\
\hline & & Accuracy & $(0.01037,0.01984,0.04394)$ \\
\hline & & Interoperability & $(0.00516,0.01174,0.02541)$ \\
\hline & & Compliance & $(0.00443,0.01105,0.02268)$ \\
\hline & & Security & $(0.00804,0.01469,0.03137)$ \\
\hline & Reliability & Maturity & $(0.00495,0.01238,0.02826)$ \\
\hline & & Fault tolerance & $(0.01282,0.02490,0.04902)$ \\
\hline & & Recoverability & $(0.01546,0.02965,0.05912)$ \\
\hline & Usability & Understandability & $(0.00086,0.00438,0.01301)$ \\
\hline & & Learnability & $(0.00284,0.01090,0.02822)$ \\
\hline & & Operability & $(0.00233,0.00905,0.02372)$ \\
\hline & Efficiency & Time behavior & $(0.01771,0.03476,0.07355)$ \\
\hline & & Resource behavior & $(0.01311,0.02844,0.06104)$ \\
\hline & Maintainability & Analyzability & $(0.01001,0.01820,0.03894)$ \\
\hline & & Changeability & $(0.00885,0.01720,0.03638)$ \\
\hline & & Stability & $(0.00492,0.01138,0.02742)$ \\
\hline & & Testability & $(0.00800,0.01576,0.03446)$ \\
\hline & Portability & Adaptability & $(0.00761,0.01472,0.02946)$ \\
\hline & & Installability & $(0.00429,0.00928,0.02146)$ \\
\hline & & Conformance & $(0.00448,0.00883,0.02016)$ \\
\hline & & Replaceability & $(0.00554,0.01246,0.02652)$ \\
\hline \multirow[t]{11}{*}{ Management } & Vender & Market share \& reputation & $(0.01078,0.02323,0.04458)$ \\
\hline & & Industrial credential & $(0.02372,0.04165,0.07429)$ \\
\hline & & Service \& support & $(0.02079,0.03568,0.06894)$ \\
\hline & & Training solution & $(0.01596,0.02919,0.05686)$ \\
\hline & Cost & Software cost & $(0.02923,0.05508,0.09890)$ \\
\hline & & Hardware cost & $(0.03512,0.06885,0.12242)$ \\
\hline & & Annual maintenance & $(0.04195,0.07573,0.12578)$ \\
\hline & & Staff training & $(0.04043,0.07573,0.11757)$ \\
\hline & $\begin{array}{l}\text { Implementing } \\
\text { time }\end{array}$ & Planning \& preparation & $(0.03279,0.05779,0.09987)$ \\
\hline & & BPR \& system tuning & $(0.04071,0.07064,0.12369)$ \\
\hline & & Testing \& go-live & $(0.07461,0.12843,0.23635)$ \\
\hline
\end{tabular}


Table 3 Fuzzy scores of the ERP software relative to the first criteria "Suitability" for company A

\begin{tabular}{cc}
\hline ERP software & Fuzzy score \\
\hline I & $(0.228,0.287,0.358)$ \\
II & $(0.200,0.249,0.347)$ \\
III & $(0.163,0.231,0.331)$ \\
IV & $(0.149,0.233,0.315)$ \\
\hline
\end{tabular}

Table 4 Computation result of the ERP software for company A

\begin{tabular}{cccc}
\hline ERP software & Computation result & Center of gravity & Rank \\
\hline I & $(0.09173,0.24763,0.64483)$ & 0.32806 & 3 \\
II & $(0.10018,0.25799,0.66576)$ & $\underline{0.34131}$ & $\underline{1}$ \\
III & $(0.09219,0.24141,0.63535)$ & 0.32298 & 4 \\
IV & $(0.10033,0.25297,0.65540)$ & 0.33623 & 2 \\
\hline
\end{tabular}

\section{Company B: Chain Store Retailer Service Industry}

Background illustration

Company B is the biggest chain store retailer of home improvement in Taiwan. This company owns over 20 direct stores in Taiwan and the business revenue is over 300 million US dollars per year. The company hires a staff of 1,500 people and there are over 30,000 merchandises for sale. Due to the sales and size of company is growing up and the number of upstream supplier is more than 500 firms, there are over 30,000 orders per week.

Thus, the company B decides to spin-off the MIS department and establishes a subsidiary company to manage the data transaction of parent company B. Through this project, company $\mathrm{B}$ determines to replace the information system of entire company.

Stage 1: Project initiation and requirements identification

The general manager of company $B$ organizes the project team including seven senior managers of different departments: administration, finance, warehouse management, supplier management, store management, purchase and a senior manager of the subsidiary company. The general manager also brings several distinctive requirements and the qualified ERP systems should provide the following functions:

(1) The original POS (point of sales system) and EOS (electronic order system) must be integrated in the new ERP system. 
(2) The ERP system should include the CRM (customer relationship management) functions.

(3) The inventory return rate should be improved.

(4) The lead time and inventory level should be reduced.

(5) The delivery rate should above $98 \%$.

(6) The stock-out rate should below $10 \%$

Stage 2: Feasible software search and selection criteria extraction

After the preliminary elimination, the identical four feasible ERP software alternatives I, II, III and IV are sifted out.

Stage 3: Hierarchy construction for ERP software

The hierarchy structure with layer $0^{\text {th }}, 1^{\text {st }}, 2^{\text {nd }}$ and $3^{\text {rd }}$ for company $B$ is the same as company A (see Figure 3).

Stage 4: Computing by FAHP approach

By using the set of question of Table 1 and calculating the fuzzy weights of each layer by eight decision makes, the final fuzzy weights of entire 32 criteria are calculated as shown in Table 5. Table 6 lists the fuzzy scores for three alternatives relative to the first criteria "Suitability", and the final assessment result is presented as Table 7.

Stage 5: Selecting the optimal ERP software

As shown in Table 7, the European ERP software I is the dominant solution in the final rank. And the project team agrees that software $I$ is the optimal decision for company B.

\section{Comparison of Semiconductor Industry and Chain Store Retailer Industry}

Through the presented in Table 8 as below, time issue is the most important criteria to both manufacturing industry and service industry. But there are still lots of criteria existing variation between various industries. It reflects the business functions and particular requirements in different industries. 
Table 5 Final fuzzy weights of entire 32 criteria for company B

\begin{tabular}{|c|c|c|c|}
\hline \multicolumn{3}{|c|}{ Hierarchy of criteria } & \multirow{2}{*}{ Fuzzy weight } \\
\hline Attribute & Major criteria & Sub criteria & \\
\hline \multirow[t]{21}{*}{ Software quality } & Functionality & Suitability & $(0.01537,0.02866,0.06443)$ \\
\hline & & Accuracy & $(0.01481,0.03140,0.07380)$ \\
\hline & & Interoperability & $(0.00744,0.01444,0.03396)$ \\
\hline & & Compliance & $(0.00416,0.00963,0.02056)$ \\
\hline & & Security & $(0.01553,0.02527,0.05232)$ \\
\hline & Reliability & Maturity & $(0.00946,0.01636,0.03468)$ \\
\hline & & Fault tolerance & $(0.01696,0.02749,0.05614)$ \\
\hline & & Recoverability & $(0.02403,0.04180,0.08024)$ \\
\hline & Usability & Understandability & $(0.00635,0.01384,0.02957)$ \\
\hline & & Learnability & $(0.01244,0.02527,0.04767)$ \\
\hline & & Operability & $(0.01409,0.02618,0.05043)$ \\
\hline & Efficiency & Time behavior & $(0.02277,0.04096,0.06793)$ \\
\hline & & Resource behavior & $(0.01565,0.02942,0.05145)$ \\
\hline & Maintainability & Analyzability & $(0.00702,0.01265,0.02645)$ \\
\hline & & Changeability & $(0.00861,0.01568,0.03085)$ \\
\hline & & Stability & $(0.00710,0.01362,0.02888)$ \\
\hline & & Testability & $(0.00615,0.01232,0.02591)$ \\
\hline & Portability & Adaptability & $(0.00614,0.01315,0.02775)$ \\
\hline & & Installability & $(0.00282,0.00710,0.01671)$ \\
\hline & & Conformance & $(0.00327,0.00753,0.01691)$ \\
\hline & & Replaceability & $(0.00525,0.01123,0.02354)$ \\
\hline \multirow[t]{11}{*}{ Management } & Vender & Market share \& reputation & $(0.01661,0.03599,0.07172)$ \\
\hline & & Industrial credential & $(0.03687,0.07177,0.13139)$ \\
\hline & & Service \& support & $(0.02818,0.05499,0.10542)$ \\
\hline & & Training solution & $(0.01862,0.03942,0.07574)$ \\
\hline & Cost & Software cost & $(0.02137,0.04413,0.08037)$ \\
\hline & & Hardware cost & $(0.01976,0.04167,0.07664)$ \\
\hline & & Annual maintenance & $(0.02835,0.05691,0.10352)$ \\
\hline & & Staff training & $(0.01385,0.03239,0.06414)$ \\
\hline & $\begin{array}{l}\text { Implementing } \\
\text { time }\end{array}$ & Planning \& preparation & $(0.02687,0.05524,0.10768)$ \\
\hline & & BPR \& system tuning & $(0.04195,0.07651,0.14250)$ \\
\hline & & Testing \& go-live & $(0.03663,0.06697,0.12670)$ \\
\hline
\end{tabular}


Table 6 Fuzzy scores of the ERP software relative to the first criteria "Suitability" for company B

\begin{tabular}{cc}
\hline ERP software & Fuzzy score \\
\hline I & $(0.252,0.312,0.367)$ \\
II & $(0.223,0.268,0.333)$ \\
III & $(0.159,0.195,0.241)$ \\
IV & $(0.183,0.225,0.282)$ \\
\hline
\end{tabular}

Table 7 Computation result of the ERP software for company B

\begin{tabular}{cccc}
\hline ERP software & Computation result & Center of gravity & Rank \\
\hline I & $(0.10146,0.26442,0.69393)$ & $\underline{0.35327}$ & $\underline{1}$ \\
II & $(0.09298,0.24944,0.66612)$ & 0.33618 & 2 \\
III & $(0.08818,0.23834,0.64231)$ & 0.32294 & 4 \\
IV & $(0.09413,0.24773,0.65187)$ & 0.33124 & 3 \\
\hline
\end{tabular}

\section{CONCLUSION}

This study proposes a five stage procedure for group decision makers to optimize the ERP software selection problem. The procedure introduces ISO 9126 standard to interpret the quality characteristics of ERP software, hence, a more specialized overall concept is conducted for ERP selection problem. Fuzzy AHP method is also applying to evaluate the ERP software alternatives of a real-world decision making problem.

According to the two successfully empirical cases in various industries, our proposed procedure is practical and flexible for use. Among the cases study, there are 32 criteria sifted out from two attributes, software quality attribute and management attribute, respectively. Base on the comparison between semiconductor industry of company A and chain store retailer industry of company B, we found that various industries exists diverse weight priorities between criteria. However, we also discovered that time issue is the most important criteria to both manufacturing industry and service industry. 
Table 8 Comparison between company A and company B for entire 32 criteria's fuzzy weights

\begin{tabular}{|c|c|c|c|c|}
\hline $\begin{array}{l}\text { Attribute } \\
\text { Major criteria } \\
\text { Sub criteria }\end{array}$ & $\begin{array}{l}\text { Center of gravity } \\
\text { of fuzzy weights } \\
\text { (company A) }\end{array}$ & $\begin{array}{c}\text { Center of gravity } \\
\text { of fuzzy weights } \\
\text { (company B) }\end{array}$ & $\begin{array}{c}\text { Rank } \\
\text { (company A) }\end{array}$ & $\begin{array}{c}\text { Rank } \\
\text { (company B) }\end{array}$ \\
\hline \multicolumn{5}{|l|}{ Software quality } \\
\hline \multicolumn{5}{|l|}{ Functionality } \\
\hline Suitability & 0.02302 & 0.03615 & 17 & 15 \\
\hline Accuracy & 0.02472 & 0.04000 & 16 & 13 \\
\hline Interoperability & 0.01410 & 0.01861 & 26 & 22 \\
\hline Compliance & 0.01272 & 0.01145 & 28 & 30 \\
\hline Security & 0.01803 & 0.03104 & 21 & 18 \\
\hline \multicolumn{5}{|l|}{ Reliability } \\
\hline Maturity & 0.01520 & 0.02017 & 23 & 21 \\
\hline Fault tolerance & 0.02891 & 0.03353 & 14 & 16 \\
\hline Recoverability & 0.03474 & 0.04869 & 11 & 7 \\
\hline \multicolumn{5}{|l|}{ Usability } \\
\hline Understandability & 0.00608 & 0.01659 & 32 & 24 \\
\hline Learnability & 0.01399 & 0.02846 & 27 & 20 \\
\hline Operability & 0.01170 & 0.03024 & 29 & 19 \\
\hline \multicolumn{5}{|l|}{ Efficiency } \\
\hline Time behavior & 0.04201 & 0.04389 & $\underline{9}$ & 11 \\
\hline Resource behavior & 0.03420 & 0.03217 & $\overline{12}$ & 17 \\
\hline \multicolumn{5}{|l|}{ Maintainability } \\
\hline Analyzability & 0.02238 & 0.01537 & 18 & 27 \\
\hline Changeability & 0.02081 & 0.01838 & 19 & 23 \\
\hline Stability & 0.01457 & 0.01653 & 25 & 25 \\
\hline Testability & 0.01940 & 0.01479 & 20 & 28 \\
\hline \multicolumn{5}{|l|}{ Portability } \\
\hline Adaptability & 0.01726 & 0.01568 & 22 & 26 \\
\hline Installability & 0.01168 & 0.00888 & 30 & 32 \\
\hline Conformance & 0.01116 & 0.00924 & 31 & 31 \\
\hline Replaceability & 0.01484 & 0.01334 & 24 & 29 \\
\hline \multicolumn{5}{|l|}{ Management } \\
\hline \multicolumn{5}{|l|}{ Vender } \\
\hline Market share \& reputation & 0.02619 & 0.04144 & 15 & 12 \\
\hline Industrial credential & 0.04655 & 0.08001 & $\underline{8}$ & $\underline{2}$ \\
\hline Service \& support & 0.04180 & 0.06287 & $\underline{10}$ & $\underline{\overline{6}}$ \\
\hline Training solution & 0.03400 & 0.04460 & 13 & $\underline{10}$ \\
\hline \multicolumn{5}{|l|}{ Cost } \\
\hline Software cost & 0.06107 & 0.04862 & $\underline{7}$ & $\underline{8}$ \\
\hline Hardware cost & 0.07546 & 0.04603 & $\underline{5}$ & $\underline{9}$ \\
\hline Annual maintenance & 0.08115 & 0.06293 & $\underline{2}$ & $\underline{5}$ \\
\hline Staff training & 0.07791 & 0.03679 & $\underline{4}$ & $\overline{14}$ \\
\hline \multicolumn{5}{|l|}{ Implementing time } \\
\hline Planning \& preparation & 0.06349 & 0.06326 & $\underline{6}$ & $\underline{4}$ \\
\hline BPR \& system tuning & 0.07834 & 0.08699 & $\underline{3}$ & $\underline{1}$ \\
\hline Testing \& go-live & 0.14646 & 0.07677 & 1 & 3 \\
\hline
\end{tabular}




\section{REFERENCES}

APICS Dictionary, 9th ed (1998). APICS-The Educational Society for Resource Management. Alexandria, VA.

Bache, R. \& Bazzana, G. (1994). Software Metrics for Product Assessment. McGrawHill, England.

Bernroider, E. \& Koch, S. (2001). ERP selection process in midsized and large organizations. Business Process Management Journal 7(3), 251-257.

Bingi, P., Sharma, M.K. \& Godla, J.K. (1999). Critical issues affecting and ERP implementation. Information Systems Management 16(3), 30-36.

Boehm, B.W., Brown, J.R., Kaspar, H., Lipow, M. MacLeod, F.J. \& Merritt, M.J. (1978).Characteristics of Software Quality. TRW Series of Software Technologies 1, North-Holland, Amsterdam.

Buckley, J.J. (1985). Fuzzy hierarchical analysis. Fuzzy Sets and Systems 17, 233-247.

Buss, M.D.J. (1983). How to rank computer projects. Harvard Business Review 61(1), 118-125.

Butler, J. (1999). Risk management skills needed in a packaged software environment. Information System Management 16(3), 15-20.

Buyukozkan, G., Kahraman, C. \& Ruan, D. (2004). A fuzzy multi-criterial decision approach for software development strategy selection. International Journal of General Systems 33(2-3), 259-280.

Buyukozkan, G. (2004). Multi-criteria decision making for e-marketplace selection. Internet Research-Electronic Networking Applications and Policy 14(2), 139154.

Cheng, C.H. \& Lin, Y. (2002). Evaluating the best main battle tank using fuzzy decision theory with linguistic criteria evaluation. European Journal of Operational Research 142, 174-186.

Everdingen, Y.V., Hillegersberg, J.V. \& Waarts, E. (2000). ERP adoption by European midsize companies. Association for Computing Machinery. Communicaitons of the CAM 43(4), 27-31.

Grady, R.B. \& Caswell, D.L. (1987). Software Metrics: Establishing a Company-Wide Program, Prentice-Hill.

Herrera, F. \& Herrera-Viedma, E. (2000). Linguistic decision analysis: steps for solving decision problems under linguistic information. Fuzzy Sets and Systems 115, 6782. 
Holland, C.P. \& Light, B. (1999). A critical success factors model for ERP implementation. IEEE Software 16(3), 30-36.

Hsu, T.H. (1999). Public transport system project evaluation using the analytic hierarchy process: a fuzzy Delphi approach. Transportation Planning and Technol 22, 229246.

Huang, L. C. \& Wu, R.Y.H. (2005). Applying fuzzy analytic hierarchy process in the managerial talent assessment model—An empirical study in Taiwan's semiconductor industry. International Journal of Technology Management 30(1/2), 105-130.

International Standard 9126 (1991). Information Technology—Software Evaluation. Quality Characteristics and Guidelines for their Use, ISO.

Kapp, K.M. (2001). Integrated Learning for ERP Success: A Learning Requirements Planning Approach. CRC Press LLC, Florida.

Kumar, V., Maheshwari, B. \& Kumar, U. (2002). Enterprise resource planning system adoption process: a survey of Canadian organizations. International Journal of Production Research 40(3), 509-523.

Langenwalter, G.A. (2000). Enterprise Resources Planning and Beyond Integrating Your Entire Organization. CRC Press LLC, Florida.

Lee, J.W. \& Kim, S.H. (2000). Using analytic network process and goal programming for interdependent information system project selection. Computers \& Operations Research 27, 367-382.

McCall, J., Richards, P. \& Walters, G. (1977). Factors in Software Quality. NTIS ADA049-014, 015, 055.

Nixon, B.A. (2000). Management of performance requirements for information systems. IEEE Transactions on Software Engineering 26(12),1122-1146.

Pressman, R.S. (2001). Software Engineering: A practitioner’s Approach. McGraw-Hill, Singapore.

Rao, S.S. (2000). Enterprise resource planning: business needs and technologies. Industrial Management \& Data Systems 100(2), 81-88.

Saaty, T.L. (1980). The Analytic Hierarchy Process, McGraw-Hill, New York.

Santhanam, R. \& Kyparisis, G.J. (1995). A multiple criteria decision model for information system project selection. Computer \& Operations Research 22(8), 807-818. 
Santhanam, R. \& Kyparisis, G.J. (1996). A decision model for interdependent information system project selection. European Journal of Operation Research 89, 380-399.

Schniederjans, M. J. \& Wilson, R.L. (1991). Using the analytic hierarchy process and goal programming for information system project selection. Informaiton \& Management 20, 333-342.

Scott, J. E. \& Kaindl, L. (2000). Enhancing functionality in an enterprise software package. Information \& Management 37, 111-122.

Talluri, S. (2000). An IT/IS acquisition and justification model for supply-chain management. International Journal of Physical Distribution \& Logistics 30(3/4), 221-237.

Verville, J. \& Halingten, A. (2003). A Six-Stage model of the buying process for ERP software. Industrial Marketing Management 32, 585-594.

Wang, J. \& Lin, Y.I. (2003). A fuzzy multicriteria group decision making approach to select configuration items for software development. Fuzzy Sets and Systems 134, 343-363.

Wei, C.C., Chien, C.F. \& Wang, M.J. (2005). An AHP-based approach to ERP system selection. International Journal of Production Economics 96, 47-62.

Wei, C.C. \& Wang, M.J. (2004). A comprehensive framework for selecting an ERP system. International Journal of Project Management 22, 161-169. 
